

\title{
Financial Management Challenges In Small and Medium-Sized Enterprises: A Strategic Management Approach
}

\section{Hande Karadag}

Wharton School, University of Pennslyvania, Sol C. Snider Entrepreneurial Research Center, | email: hkaradag@wharton.upenn.edu

Volume 5 No 1 (2015) ｜ＩSSN 2158-8708 (online) ｜ＤOI 10.5195/emaj.2015.67 | http://emaj.pitt.edu |

Abstract

Due to their significant role in creation of new jobs, rise in GDP, entrepreneurship and innovation, small and medium-sized enterprises (SMEs) are recognized as the drivers of socio-economic growth, both in developed and developing economies. In Turkey, $99.9 \%$ of all enterprises fall into SME category. Therefore, the significance of SMEs for Turkish economy and society is much higher in Turkey, compared to other emerging and developed countries. Small and medium-sized companies are faced with a number of challenges whereas the problems arising from "poor financial management" are reported as the major causes of business failures in SMEs. Strategic financial management (SFM) which is a research area that has attracted the interest of researchers after 2010, is one of the key managerial areas of SMEs, due to its vital role on the survival, growth and performance of SMEs. The purpose of this paper is to analyze the central role of financial management and identify the financial management challenges and practices that influence the organizational performance in Turkish SMEs, from a strategic management perspective. Within the course of this paper, the importance and challenges of SMEs in Turkey are presented in the first section, while the literature on strategic and financial management in SMEs is reviewed in the second part. In the third section, the recent strategic financial management concept, the implications of strategic financial management practices for SMEs in Turkey and the relationships between strategic financial management practices and SME performance, are discussed. Small and medium sized enterprise finance in Turkey is a developing research area; therefore this paper aims to make a significant contribution to the existing literature by analyzing the major challenges at the conduct of financial management in Turkish SMEs and the influence of strategic financial management practices on the performances of small and medium sized companies in Turkey. Additionally, the conceptual framework developed is expected to be useful to academics in developing an agenda for future empirical research.

Keywords : SMEs, financial management, strategic management, strategic financial management (SFM) practices

(cc) BY

New articles in this journal are licensed under a Creative Commons Attribution 3.0 United States License.

\section{UILIS D-Sonk}

This journal is published by the University Library System of the University of Pittsburgh as part of its D-Scribe Digital Publishing Program, and is cosponsored by the University of Pittsburgh Press. 
Financial Challenges In Small and Medium-Sized Enterprises: A Strategic Approach Management

\author{
Hande Karadag
}

\section{Introduction}

Small and medium sized enterprises (SMEs) form a large part of economy and are regarded as the drivers of socio-economic development in all countries. In OECD countries, over $95 \%$ of all enterprises fall in the SME category, while over $50 \%$ of the private sector employment is supplied by SMEs (Lukacs, 2005). Although most of the enterprises in all countries are SMEs (Özdemir, Ersöz \& Sarığlu, 2011) the interest to micro, small and mediumsized companies both among practitioners and academics is quite recent. The importance of SMEs in the economy has been widely recognized after 1980 's, as the focus shifted from large corporations smaller sized enterprises. Since then, these economic units are regarded as the core of developmental macro and socioeconomic policies on both national and international levels.

In Turkey, the significance of SMEs is relatively higher, which is caused by not only their large share, amounting to $99.9 \%$ of all formally declared businesses in the economy, but also from their resilience to the shocks in turbulent Turkish macro economy. Turkish SMEs, which were faced with serious challenges during and after the severe economic crises that hit the Turkish economy within the last three decades, increased their share in the economy significantly, while Turkish government took radical steps towards attaining a more stable macro economy and sustainable growth. During that restructuring period, SMEs became one of the key elements of the macroeconomic improvements in Turkey, due to their significant role in the growth of overall GDP, new job creation and exports.

Despite the positive outlook and growth trends of the sector, SMEs in Turkey, as in most developing economies, are faced with a number of challenges, such as insufficient managerial skills, lack of trained personnel, poor access to financial resources and low utilization of new technologies. Among these, lack of an efficient and effective financial management system is a core problem area for Turkish SMEs. As financial management is the centre of the overall management system in a small business (Meredith, 1986) the ineffectiveness and inefficiencies of financial conduct have detrimental effects on the longevity and performance of an SME. As most problems of SMEs have a financial nature (OECD, 2006), poor financial management is a critical and common cause of business failures in SMEs (Jindrichovska, 2013). Particularly lack of financial management knowledge combined with uncertainty of the business environment often leads SMEs to face serious problems regarding financial and overall performances, which can even threaten the survival of the enterprise (Kaya \& Alpkan, 2012).

As Turkey is a developing country where insufficient levels of equity capital and poor access to external finance are considered as the major financial challenges for SMEs (Öndeş and Güngör, 2013; Şahin, 2011; Çetin, Akyüz and Genç, 2011; Güler, 2010; Koyuncugil and Özgülbaş, 2008), previous literature on financial characteristics of Turkish SMEs focused mainly on financial problems of small and medium sized companies with respect to their funding requirements (Uluyol, 2013; Koyuncugil \& Özgülbaş, 2008; Topal, Erkan \& Elitaş, 2006; Arslan, 2003), the research area of financial management practices in SMEs in Turkey has been significantly neglected up to date. Therefore, this paper aims to make a contribution to the literature by analyzing the major financial management challenges of SMES in Turkey, and the practices of financial management which are closely related to SME performance, in other terms, which have a "strategic" importance in terms of improving or worsening the performance of the SME. The conduct of financial strategies formulated by the owners and/or managers of the enterprises is a concept which can show variations among different contexts, as which financial practices are more common or more strategic importance in the overall financial management of SMEs can differ from one setting to another, depending on the development of the context of corporate sector (Butt, Hunjra and Rehman, 2010). However, the questions regarding how these practices can be identified within their own contexts and used as strategic tools for overcoming the financial and overall managerial challenges and attaining a higher organizational performance, have not been investigated in depth. Thus, as an additional contribution, the conceptual framework developed within this study can provide a basis to academics for future empirical research. Within the course of the paper, Section 2 briefly reviews the literature on the concept of SME and the importance and challenges of SMEs in Turkey. Section 3 starts with the analysis on strategic management in SMEs, and continues with identification of strategic financial management practices in small and medium sized companies, both in international and local contexts, by introducing a "strategic management model of financial practices in SMEs". The details of the model constructs as well as their role on the overall performance of the SME are presented in the same section. The implications of strategic financial management practices for academics and practitioners are discussed in section 4. 


\section{II . Significance and challenges of SME sector in Turkey}

\section{The SME concept}

There are different categorizations of small and mediumsized enterprises due to varying socio-economic conditions of each economic region or country focused. While Storey (1994) argues that "there is no single definition" of the SME concept, Bolton Committee Report (1971) describes SMEs as the "enterprises with a relatively small share of the market, managed by owners or part-owners in a personalized way, and not through the medium of a formalized management structure; and acting as separate entities, in the sense of not forming part of large enterprise or group" (Bolton Report, 1971). SMEs and entrepreneurship are accepted "to be a key source of dynamism, innovation and flexibility in advanced industrialized countries, as well as in emerging and developing economies" (OECD, 2006). SMEs are called as the "backbone of the European economy" as they constitute $98 \%$ of all enterprises with a total of 20.7 million businesses and account for $67 \%$ of total employment and $58 \%$ of gross value added in European Union, as of 2012 (EC,2012).

The role of SME's in social and economic development has been widely recognized in developed countries as well as developing economies (OECD,2006) particularly after 1980 's. SME development is "closely linked with growth" (Ardiç, Mylenko and Saltane, 2011; Beck, 2010) as the researchers found out "a robust, positive relationship between the relative size of the SME sector and economic growth, even when controlling for other growth determinants" (Ardıç, et al., 2011; Beck, 2010). Apart from their role in GDP growth, SMEs have other significant socio-economic characteristics such as their contribution to new job creation and reduction of poverty. The potential economic and social benefits of SMEs can be stated as "creating jobs at low cost of capital, contributing positively to the Gross Domestic Product (GDP), improving forward and backward linkages between sectors, creating opportunities for employing appropriate technology, providing an opportunity to expand the entrepreneurial base, expanding a pool of skilled and semiskilled workers, providing support to large-scale enterprises, providing the required flexibility to adapt to market failures, entering into market niches which are not profitable for larger enterprises, contributing to development policies that are more oriented towards decentralization and rural development, supporting governments' efforts alleviate the negative aftermath of structural adjustment programs" (Zonooz, Farzam, Satarifar \& Bakshi, 2011; Tolentino, 1995).

Small and medium-sized companies are often viewed as being more innovative than larger firms and considered to follow niche strategies in developed countries, while adopting "high product quality, flexibility and responsiveness to customer needs as means of competing with large-scale mass producers" (Hallberg, 2000; Snodgrass and Biggs, 1996). SMEs emerged as the key economic actors in both developed and developing economies, within the last three decades, particularly due to the shift towards a more global business context and developments in information technologies.

Despite their several advantages over large-sized competitors, small and medium sized enterprises have weaknesses and challenges of their own. Zimmerer and Scarborough (2005) state "managerial mistakes, failure to develop a strategic plan and poor financial control" among the most important reasons of business failures in small businesses, ranking "poor management" as the primary cause. Among various problems of SMEs, financial challenges have a unique situation as, according to OECD reports, most problems of SMEs have a financial nature (OECD, 2004, 2006). In the study performed by Hall and Young in UK (1991), 86,6\% of the respondents reported that, the reasons of their business failures had a financial nature (Hall and Young, 1991). The correlations between outcomes of the financial strategies and decisions and the performance of the enterprise have also been well documented by various researchers (Salazar, Soto and Mosquedo, 2012). SMEs in developing economies are more prone to experiencing finance-related difficulties, particularly with respect to external funding (OECD, 2006).

\section{SMEs in Turkey}

According to the bylaw dated 04.11.2012 and published in the Official Gazette of Turkish Republic, the SME definition in terms of employee number and annual revenue in Turkey is as follows:

\begin{tabular}{|l|c|c|}
\hline & $\begin{array}{c}\text { Number of } \\
\text { employees }\end{array}$ & $\begin{array}{c}\text { Annual } \\
\text { turnover }\end{array}$ \\
\hline Micro Enterprises & $<10$ & $<1$ million TL \\
\hline Small Enterprises & $<50$ & $<8$ million TL \\
\hline $\begin{array}{l}\text { Medium-sized } \\
\text { Enterprises }\end{array}$ & $<250$ & $<40$ million TL \\
\hline
\end{tabular}

SMEs are the most significant tools for economic development, gross domestic product and workforce in Turkish economy (Nurrachmi, Abd Samad \& Foughali, 2012). There are a total of 3,222,133 small and mediumsized enterprises in Turkey, which constitute $99.9 \%$ of all enterprises, while $76 \%$ of total employment, $53 \%$ of total wages and salaries, $63 \%$ of annual sales turnover, $53.3 \%$ of value added at factor cost and $53.7 \%$ of gross investment intangible goods are supplied by SME sector (Turkstat, 2013). According to main groups of industry, $40.8 \%$ of SMEs operate in wholesale and retail trade together with the repairing of motor vehicles and motorcycles, while $16.4 \%$ operate in transportation and storage industries and $12.8 \%$ work in manufacturing industry. The percentage share of SMEs within the total exports is $62,6 \%$ in 2012 , 
rising from a $56 \%$ in 2009 , where the share of micro enterprises is $20.6 \%$, small enterprises is $24.3 \%$ and medium-sized enterprises is $17.7 \%$ in total exports. The proportion of the SMEs' export and import volumes indicate the contribution of SME sector to the balance of payments deficit of Turkish economy, as the percentage share of SMEs in total exports is $38.5 \%$ in 2012, compared to their \% 62,6 share in total exports.

Despite their vital importance within the economy, SMEs in Turkey are faced with major challenges. While common problems of SMEs particularly in developing economies are mainly reported as insufficient use of new technologies, lack of business related training, inadequate managerial capabilities, high rate of taxes and other bureaucratic problems (Abdulsaleh and Worthington, 2013, Ardıç, et,al, 2011), KOSGEB, which is the main public body responsible from SMEs, reported the basic challenges experienced by SMEs in Turkey, as follows (KOSGEB, 2012) :

Technology and innovation Insufficient know-how and low levels of technology are common in most Turkish SMEs. Most manufacturers in Turkey currently operate in medium-low and low level industry sectors, reaching to a very high percentage of $89 \%$, which prevent them from benefiting low cost advantage. Low regard for innovation, due to high costs of R\&D, is a major cause of low levels of technology of SMEs. SMEs face various challenges when conducting $\mathrm{R} \& \mathrm{D}$ projects and realizing business ideas which can be turned into business opportunities. In 2012, 16.6 percent of R\&D expenditure was performed by SMEs and regarding R\&D personnel distribution, 25.3 percent was employed in SMEs (Turkstat, 2013).

Marketing and Exporting: As lack of information on foreign market opportunities, inadequate financing and technical knowledge lower the competitiveness of products and services, SMEs in Turkey mostly target the domestic market.

Entrepreneurship: With its young demographic structure, Turkey has a significant but mostly unutilized potential for entrepreneurship, where the main causes are insufficient technical knowledge on preparing business plans and difficulties in finding the startup capital, needed to undertake the high costs of launching the business.

Environment: In Turkey, as in most parts of the world, the demand for environmentally-friendly products and services is increasing. However, the complexity of environmental legislation and the height of costs to comply with the legislation are discouraging the SME owners and entrepreneurs from meeting that demand.

Labor: Due to high percentage of social security premiums, cost of skilled labor in Turkey is higher than most developing economies. This, combined with low levels of education and technical capabilities of employees, creates a major disadvantage for competitiveness of SMEs.
Administrative costs and burdens: The complexity and cost of bureaucratic transactions and the costs of launching a new business are also among the major challenges SMEs face in Turkey. While significant developments have been made regarding the attainment of a more SME-friendly business climate and "simplified legislative procedures", reduction of red-tape is an important issue for new venture launches and encouraging entrepreneurship. Among other countries, Turkey ranked as the 69rd in the "World Bank Doing Business Report"(Worldbank,2014). However, at the ranking of "starting a business", the country's rating fell significantly from 73. place to 93 between 2013 and 2014, resulting mainly from the high costs of launching a new business as illustrated in Table 1 .

Table 1. Turkey's Ratings for Starting a Business

\begin{tabular}{|l|c|c|c|}
\hline Indicator & Turkey & $\begin{array}{c}\text { Europe \& } \\
\text { Central Asia }\end{array}$ & OECD \\
\hline The total number of procedures required to register a firm & 6 & 5 & 5 \\
\hline & & & \\
\hline The total number of days required to register a firm & 6 & 12.8 & 11.1 \\
\hline & & & \\
\hline Cost is recorded as a percentage of the economy's income per capita & 12.7 & 6.7 & 3.6 \\
\hline & & & \\
\hline $\begin{array}{l}\text { The amount that the entrepreneur needs to deposit in a bank or with a notary } \\
\text { before registration and up to 3 months following incorporation (recorded asa } \\
\text { percentage of the economy's income per capita) }\end{array}$ & & & \\
\hline
\end{tabular}

Source : World Bank Doing Business Report (2014)

Financial challenges: As in most developing economies, financial difficulties are very common for most of the SMEs in Turkey. Due to collateral, personal and financial statement-related problems in utilizing bank loans and low levels of equity, SME credits are still at a low level of around $25 \%$, which is an important factor behind the low technological capacity and less modernized production facilities of SMEs. Alternate sources of finance such as angel investors, credit guarantee funds and venture capital companies are insufficient and most of the time, inaccessible, for SMEs in Turkey. In addition to that, background and knowledge level of SME owners, play an important role financial problems of SMEs. As most SME owners/managers come from a technical or engineering background, their knowledge about finance and accounting is most cases, is significantly limited. Whilst that, most SME owner/managers refrain from hiring professional finance managers for not delegating their "managerial power", which causes their financial problems to grow and even threaten the survival of their enterprises. 
Previous studies have shown that, among these several problems, challenges related with financial decisions and actions have a strategic importance for SMEs in Turkey, as the efficient and effective conduct of financial management has the potential to elevate or diminish the performance of a small and medium sized company (Öndeş and Güngör, 2013; Şahin, 2011; Çetin, Akyüz and Genç, 2011; Güler, 2010; Koyuncugil and Özgülbaş, 2008). Regarding the financial management challenges, the following section analyzes the major practices of financial management conduct in Turkish SMEs, from a fresh strategic management perspective.

\section{Strategic financial management practices}

\section{Strategic Management in SMEs}

Strategic management is "a set of managerial decisions and actions that determines the long-run performance of a corporation" (Wheelen and Hunger, 2010) As the description emphasizes, strategic management of an enterprise concerns with attaining a sustainable positive performance and contains four basic elements, which are environmental scanning, strategy formulation, strategy implementation and evaluation and control. Strategic management creates " a clearer sense of strategic vision for the firm, sharper focus on what is strategically important" and "improved understanding of a rapidly changing environment" (Wilson, 1994). Within that respect, conducting strategic management in SMEs have a crucial importance as SMEs have to operate and compete within contexts of high risk and uncertainty.

Zimmerer and Scarborough (2005) describe "strategic management" in small businesses as "the process of developing a game plan to guide a company as it strives to accomplish its vision, mission, goals, and objectives and to keep it straying off-course" (Zimmerer and Scarborough, 2005: 65). Strategic management behavior in small and medium sized enterprises involves "an attempt to cope more effectively with the great and rising demands emanating from both outside and inside the firm by (i) giving the development of the firm a long-range direction; (ii) formulating and applying an overall concept of the firm; (iii) generating, implementing, and controlling basic strategies and sub-strategies; and (iv) utilizing such special "strategic" tools as strengths/weaknesses analysis and opportunity/risk analysis, among others" (Pleitner and Barney; 1989).

The need for applying the methods and techniques of strategic management in small and medium sized businesses can be attributed to the changing conditions of conducting business. Although small businesses are exposed to higher risks and uncertainty compared to large sized enterprises, the traditional business management style of SME owners or entrepreneurs generally tended to overlook the strategic management processes, which had to go through serious changes with the developments in the business environment, as the entrepreneurs and small business owners became more aware of the challenges and the opportunities of the contexts they are competing in and the sustainable competitive advantages their enterprises had to develop, for reaching their organizational goals (Zimmerer and Scarborough, 2005). Within that respect, the potential advantages of a strategic outlook for SME owner/managers, summarized by Wickham (2006) as: "encouraging the entrepreneur or small business owner to evaluate and articulate a vision, ensuring the scanning and analyzing of the organization and its environment, facilitating the discovery of

new opportunities and strengths, guiding the restructuring of the enterprise, guiding the processes of decision making, within the enterprise, providing a starting point for the specification of objectives, acting as a common language for the enterprise's stakeholders" (Wickham, 2006) were soon realized by SME owner/managers, to targeted to maintain a sustainable organizational performance and improved levels of competitiveness.

In academic studies, until 1980's the general perspective of strategic management is regarded to be broad and non-distinctive among types of businesses, assuming a general applicability of strategic management concepts and processes of large firms to all businesses (Davig,1986). Among the few researchers whose views contrasted with this generalization were Cohn and Lindberg (1972), who stated that smaller firms needed specific strategies for survival and growth, Pleitner, et.al. (1989: 72) who pointed out the criteria of firm size and entrepreneurial types as the two bases of distinction between management of companies, and Carter (1990) who suggested that small companies faced higher adaptation problems due to "higher regulatory and competitive uncertainty" (Carter, 1990). In this new stream of thought, entrepreneur and entrepreneurial characteristics were considered to be the core of the discussion. (Dean, Brown and Bamford,1998). A recent study by Liberman, Jaoni and Hooper (2010) supported that argument, revealing that, personal characteristics of SME owner-managers, such as experience, social relationships, level of information and ethical values, strongly affects strategic decision-making processes in micro enterprises, while further models and analyses regarding the distinctions between large and small companies were not limited solely to entrepreneurial characteristics, taking other factors e.g. industry environment, firm specific competitive behaviour and strategic decision making processes in these firms, into consideration. In an empirical study, Chen and Hambrick (1995) studied 28 US airline companies and found out that, small business competitive behavior is different from that of larger firms and suggested that, small firms had higher speed in initiating strategic behavior but were low-key, even secretive in their strategy implementation. Following their study, Dean, Brown and Bramford (1998) conducted an empirical research on a large sample of US small and large manufacturing firms, where they found strong 
evidence for their proposition that "small and large firms possess different resources and capabilities that make them particularly well suited to different environmental contexts".

Due to the growing interest to the impact of strategic management on the improvement of SME performance, the role of financial decisions and actions within the overall strategic management system is becoming more popular among the scholars, particularly after the introduction of the recent strategic financial management theory by Liu, in 2010. The theory and its implications on the practices of financial management both at the international context and in Turkey, are analyzed in the following section.

\section{Strategic financial management practices}

After the studies showing that "The main causes of business failure are the lack of financial planning, limited access to funding, lack of capital, unplanned growth, low strategic and financial projection, excessive fixed-asset investment and capital mismanagement" (Salazar,Soto\&Mosqueda, 2012), the concept of strategic financial management practices in enterprises started to gain popularity among researchers.

Strategic financial management (SFM) refers to "financial management theories according to which financing should be conducted in the most proper way, the collected capital should be utilized and managed in the most effective way in enterprises and decisions on the reinvestment and distribution of profits should be made most reasonably" (Liu, 2010). Strategic financial management consists of "financial strategies which are goals, patterns or alternatives designed to improve and optimize financial management in order to achieve corporate results" where financial strategy "represents a path to achieve and maintain business competitiveness and position a company as a world-class organization" (Salazar,et.al, 2012).

Studies show that, despite the importance of strategic thinking and implementation on the conduct of financial management in SMEs which have to operate in contexts of high risks and uncertainty with limited resources, SME owner/managers regard production/service or marketing functions as priorities particularly in the startup phase of new ventures, which eventually results with poor financial management, and in most cases failure of business (Jindrichovska, 2013). It is also reported that, SME owners or entrepreneurs, until recently have a general tendency to overlook the elements of strategic management (Zimmerer and Scarborough, 2005), whereas the lack of "strategic outlook" in the financial issues is a major threat on the longevity of SMEs as "many of the factors that contribute to failure can be managed properly with strategies and financial decisions that drive growth and the organization's objectives" (Salazar, Soto, Mosqueda, 2012). While SMEs are reportedly more distant from traditional "deliberate" approach of strategic management which strictly requires the formal planning and controlling activities, their chaotic environment and the limited resources force them to be much closer to the "emergent" strategic management approach led by Mintzberg (1994), which is more flexible, leaving room to changes and developments in the environment. However, the need for the deliberate (planned) strategic management is evident in the phases of environmental scanning and the strategy formulation, while the emergent approach can be argued to be useful in the strategy implementation phase for small and medium sized companies.

Within the financial management literature, there has been a considerable amount of research focusing classifying of main constructs of financial management. Among these, Mc Mahon, Hutchinson and Forsaith (1993) have been leading researchers, analyzing and categorizing the practices of financial management in Australia, UK and US SMEs. Later, various scholars worked on several aspects of financial management practices in different contexts (Okafor,2012; Chung and Chuang, 2011; Hunjra,Butt,Rehman,2010; Pham,2010; Nguyen 2001). With regard to the independent variable of financial management practices in these studies, in contrast to the previous studies advocating a general categorization for the elements of financial management, Butt, Hunjra \& Rehman (2010) argued that, major constructs of financial management practices in SMEs can vary from one country to another, depending on the development of the context of corporate sector. Empirical studies conducted on SMEs of different countries supported their argument, indicating existence of a significant variance among the major constructs of financial management practices in different contexts of research. For example, Peel and Wilson (1996) regarded capital budgeting and financing activities as the major elements of financial management practices for small businesses in UK, while Nguyen (2001), conducting a research study on Vietnamese SMEs, argued that the practices which are more related to the profitability and performance of SMEs in Vietnam are the practices related to the 'accounting information systems, financial planning, working capital management, fixed-asset management and financial reporting and analysis" (Nguyen, 2001). Later, Kennedy and Tennent (2006) used "financial record keeping" the general indicator of financial management conduct in small businesses in Australia' and Butt, Hunjra and Rehman addressed "capital structure decision, dividend policy, investment appraisal techniques, working capital and financial assessment" as the most common financial management practices in Pakistan (Butt, Hunjra \& Rehman, 2010). In Turkey, studies conducted up to date on financial management of SMEs, indicate both similarities and diversifications with regard to previous studies conducted in other contexts, which is explained in detail in the following section.

Interestingly, no research study, to date, attempted to analyze the variances in the practices of financial management in SMEs within different contexts and 
approach the conduct of these practices from a strategic management viewpoint, taking the influence of these practices on organizational performance, as a base. The following section presents a conceptual model as a new perspective of looking at the financial conduct in small and medium sized companies, by firstly identifying the "strategic" practices of financial management in Turkey, followed by a discussion on their interrelationships and their impact on organizational performance.

\section{Strategic financial management practices and SME performance}

In Turkey, as in most developing economies, lack of capital and poor access to finance are considered as the main financial challenges for small and medium sized companies (Öndeș \& Güngör, 2013; Şahin, 2011; Cetin, Akyüz \& Genç, 2011; Güler, 2010; Koyuncugil \& Özgülbaş, 2008). While Turkey experienced the greatest expansion in SME lending among OECD countries within the period of 20072011, the proportion of the SME share in total credits is still significantly below the SME credit utilizations of the developed economies (OECD, 2012).

Whilst commercial banks are still the most common sources of SME finance in Turkey mainly due to the underdevelopment of venture capital and credit guarantee systems, problems related to collateral, credibility and financial statements inhibit the effective utilization of banks loans by the SMEs. Therefore, majority of Turkish SMEs finance their working capital needs by either using equity financing (Şahin, 2011) or other external sources such as family financing or individual loans (KOSGEB, 2011). Regarding other challenges related to financial management, inefficient use of financial resources (Uluyol, 2013) and insufficient working capital management in terms of cash inventory and receivables management constructs, are reported as key financial challenges for SMEs in Turkey. Among these, cash-flow problems have a unique situation, as the deterioration of cash-flow in an enterprise causes the owners to finance daily operations with equity capital or personal funds, and when this situation continues for long, the melting equity capital threatens the survival of an enterprise (KOSGEB, 2011). In addition to that, an efficient inventory management is stated to lead to improved competitiveness in SMEs (KOSGEB, 2011). The importance of cash and inventory management for SMEs in Turkey is also well documented in other studies (Uluyol, 2013; Kaya \& Alpkan, 2012). As other important constructs, insufficient overall and financial planning, lack of feasibility analyses before making investment decisions, inadequate keeping of financial records and lack of analyses of financial reports due to insufficient financial knowledge of SME owner/managers, are among the main problem areas of SMEs in Turkey, with respect to financial management (Kaya \& Alpkan, 2012; Alkış a\& Temizkan, 2012; Güler,2010; Kutlu \& Demirci, 2007; Arslan, 2003).
As Turkish SMEs are mainly dependent on external sources of funding, previous literature on financial problems and practices of SMEs in Turkey, has mainly focused on funding challenges in SMEs (Uluyol, 2013; Koyuncugil \& Özgülbaş, 2008; Topal, Erkan \& Elitaş, 2006; Arslan, 2003), leaving the research area of other important financial management constructs of SMEs significantly neglected, up to date. The following findings have been reported as the results of some of the empirical studies regarding financial management practices of SMEs in Turkey:

Çakır (2013) studied 58 manufacturing companies in Turkey and found out that higher cash conversion cycle is associated with higher profitability (Çakır, 2013).

Güngör and Öndeş (2013) conducted a research study on 30 SMEs in Erzurum region of Turkey. Their findings indicated that, lack of financial management knowledge and collection of receivables in working capital management are among the most common financial problems in SMEs In addition to that, $97 \%$ of these SMEs used equity financing instead of debt financing, and capacity utilization ratio in these SMEs were found to be very low, causing significant amounts of financial losses and decreases in the rate of employment. (Öndeş and Güngör, 2013).

Uluyol (2013) implemented an empirical research on financial management practices of 260 SMEs in Kahramanmaraş, Hatay, Şanlıurfa, Adıyaman and Gaziantep cities of southeastern region of Turkey. The findings implied that, the conduct financial management practices is "unsatisfactory" in SMEs, as most practices are reported to be "partially" undertaken. The major implication of the research study was the reporting of a general lack of financial knowledge in practices of financial management.

Güler (2010) investigated the working capital management and other financial management practices in 111 SMEs in Ankara region of Turkey and found that SMEs mostly use the payback period method, when making fixed-asset investment decisions. The findings also indicate that, SMEs have the highest regard for the collection of receivables and cash flow management, as practices of working capital management.

Çetin and Bitırak (2009) carried out an empirical study about financial management, working capital and investment budgeting practices of 40 SMEs in Antalya city of Turkey. Findings of their research indicated that, followup of doubtful receivables and managing cash are the basic working capital management practices in SMEs, while payback period method is the most widely used method in fixed-asset investments.

Çetin, Akyüz and Genç (2008) conducted a research on SMEs in Usak city of Turkey and found out that $80 \%$ of the SMEs did not have a finance department, 
and majority of them faced difficulties at collecting their receivables and utilizing bank loans, while $85 \%$ had to postpone their investment plans during the economic crisis period of 2008-2009.

Koyuncugil and Özgülbaş (2008) studied the financial data of 697 SMEs which are quoted to İstanbul Stock Exchange. The findings of their analysis presented that, $62 \%$ of these SMEs' financial performance was weak, compared to with the others. The SMEs with lower scores had the common problems of low ROE and net profit margin, faced difficulties in the collection of receivables and had financial management problems (Koyuncugil and Özgülbaş, 2008)

Çetin (2006) studied financial management, working capital and fixed-asset budgeting practices of 42 SMEs in Antalya and Isparta cities in the Mediterennian region of Turkey. Findings of the study indicated that the SME owner/managers are not well- informed about money and capital markets, as well as about basic concepts of financial management. About the practices of working capital management, SMEs considered collection of receivables and practices of inventory management, as important. SMEs also regarded acquisition of basic machinery and equipment, as their core investments in fixed-assets.

Topal, Erkan and Arıtaş (2006) conducted a study about financial management practices of 48 SMEs in Afyonkarahisar city of Turkey. Findings of their study indicated that, machinery and equipment acquisitions, conducted with the motivation of growth of business volumes, are the basic fixed-asset investments and SMEs use profitability and pay-back analyses in assessing their fixed-asset investments. SMEs also reported frequent uses of working capital management practices, most important ones being receivables and inventory management, but also including cash budgeting and follow-up of periodical monetary target

While the literature on SME strategic management suggests that SME owner/managers do not always employ the processes of strategic management when running their businesses (Zimmerer \& Scarborough, 2005), the empirical studies conducted on financial management constructs of Turkish SMEs present indicators of employment of an "emergent" approach of strategic management at the implementation phase of the conduct of financial management practices, particularly when managing daily financial operations and during processes of large investments. On the other hand, the owner/managers of SMEs experience problems in taking a "deliberate" approach of strategic management, regarding the strategy formulation and feedback and control phases of financial management, which results in poor financial and overall organizational performance results. The flow of financial management practices and the phases deliberate and emergent illustrated in the strategic management model of financial management practices in SMEs, as shown in
Figure 1. Within the three basic phases of strategic financial management, SME owner/managers in Turkey tend to have a higher regard for the implementation phase of financial management practices, such as paying more attention to the daily transactions related to various working capital management practices including cash, receivables, inventory and accounts payables management, as well as making detailed evaluations before making fixed-asset investments. This indicates that, the "emerging" approach of strategic management which also facilitates finding immediate solutions to unanticipated financial problems with its unstructured and flexible nature is common among Turkish SMEs, in their conduct of financial management. On the other hand, the "deliberate" strategic management approach, regarding the elements of strategy formulation and control, is found to be in much lower levels, as most SME owner/managers reportedly do not show a great interest or lack the technical knowledge related with the financial planning and the financial reporting and control practices, which eventually become significant factors of poor performance results and even failure of business.

The flow and interrelationships of the strategic financial management practices with respect to SME performance are illustrated in the strategic management model of financial management practices in Figure 1. The strategic financial management elements of the model, namely financial planning, working capital management with three sub-constructs of cash, receivables and inventory management, fixed-asset management and finally, financial reporting and control, are determined according to the significance of their correlations with the overall performance of the company, as regarded by the SME owner/managers. Other elements of financial management, such as accounting information systems, are not included in the model, as these practices have been reported by the SME owner/managers, as being significantly correlated with SME performance in Turkey.



Figure 1: Strategic management model of financial management practices in SMEs 
The inadequacy of an effective and efficient conduct of financial management and the challenges regarding main practices of financial management in Turkish SMEs are well documented in several studies (Uluyol, 2013; Koyuncugil \& Ozgulbas, 2008; Cetin, 2006). Therefore, the conceptual model is designed to identify the key practices of financial management and deriving proposals about how the model can be used as a "strategic tool' for overcoming the financial management problems in order to attain a higher organizational performance in small and medium size companies.

Strategic financial planning: Problems related with access to financial resources are vital for Turkish SMEs. However, studies show that the planned, accurate and goal-oriented utilization of the acquired funds is more critical for a successful SME performance (Uluyol, 2013). A high regard for financial planning resulting with the development of "a solid financial plan" (Zimmerer and Scarborough, 2005) is considered as the key for launching and operating a successful enterprise, as the lack of financial planning and projection is argued to be one of the major causes of business failures, particularly in SMEs (Malette, 2006). Within the overall financial management system, financial planning can have several major functions, such as raising the required capital for the start-up phase of the enterprise or efficient and effective management of enterprise's daily operations. Any process of strategic management starts with "strategy formulation", where environmental scanning is undertaken for identifying the factors which have the potential to affect the organization's survival and success, followed by the formulation of strategies for reaching organizational goals. While the conduct of financial planning is executed when managing daily operations of the company, such as making deciding on the receivables collection period or bank credit maturities and amounts, a more strategic outlook adds a 'long-ranged view' and 'goal-orientation' elements to overall managerial perspective, resulting with the direction and focusing of the limited financial resources towards the required ends. Therefore, this "seeing the big picture" and formulating financial plans and actions accordingly, contributes to the improvement of both financial and overall performance of the company, to a large extent. This phase is very critical for every company, as lack of strategy formulation results in a "going with the flow" style of management and eventually ineffective and inefficient use of resources and low organizational performance. Formulation of financial strategies is important for small and medium sized companies as well as large corporations, as SMEs have to compete with very limited resources in contexts of high risk and uncertainty. Therefore, it can be proposed that, an effective and efficient strategic financial planning would result with improved performance in small and medium sized companies.
Proposition 1 : Strategic financial planning has a positive impact on SME performance.

Strategic working capital management: Working capital management has a particular importance for firms in emerging markets, as the companies operating in these countries are mostly SMEs who have limited access to long-term capital markets, therefore are much reliant on owner financing,, trade credits and inventories to finance their funding requirements for cash, accounts receivables and inventories (Abuzayed, 2011). Studies show that, in Turkey, as in most developing economies, cash, receivables and inventory management are the key areas of financial management where SME owner/managers allocate most of their time as they regard these practices as "strategic" for their enterprises. Despite this high managerial awareness, interestingly, most business failures are reported to result from the ineffective and inefficient management of working capital, particularly cash and receivables (Uluyol, 2013; Kaya and Alpkan, 2012), implying the presence of serious deficiencies in the strategic thinking and implementation processes regarding the management of working capital. As the follow-up and collection of doubtful receivables and bad debts, the management of inadequate or excess cash and the finding and keeping of optimum levels of inventory are highly important for the survival and performance of small and medium sized enterprises, SME owner/managers create snapshot solutions to immediate crises at these areas. Therefore, it can be argued that they tend to apply a more emergent strategic management approach when dealing with conflicts and problems about the management of working capital. The key point therefore, which would differentiate a successful and highly performing SME from an unsuccessful one, is how effectively and efficiently the process of strategic management is carried out by the SME owner/managers. Empirical studies show that, the profitability of the enterprise can be increased by accurately managing the cash in and out movements, besides minimizing the amount of excess cash (Block and Hirt, 2004) or reducing the number of days of cash collection period, showing that the enterprise has the ability to shorten its receivables collection period or lengthen its accounts payable period (Cakir, 2013; Gul, et. al, 2013). Efficiency and effectiveness in inventory management is the final critical factor in working capital management in SMEs as inventories generally form the largest asset on the balance sheet. SME owner/managers are more prone to utilize the "observation method" for detecting the amount of inventory, which causes them to face problems due to having too much or too little inventories, resulting with either low customer satisfaction or high costs of financing excess levels of inventory (Hodgetts and Kuratko, 1998). However, in Turkey, management of inventories has the least managerial priority compared to cash and receivables management, which constitutes the other important reason for high inventory costs, decreasing profitability and eventually poor financial performance (Cetin, 2006; Topal, Erkan \& Arıtaş, 2006). Combining the influence of the three key factors of working capital management over SME performance, it can be stated that, an SME which has a 
higher regard for a strategic approach when managing its working capital would be more successful in terms of financial and overall performance.

Proposition 2: Strategic working capital management has a positive impact on SME performance.

Strategic fixed-asset (capital budgeting): Despite that the decision about whether to make a fixed-asset investment is crucial to SMEs regarding the impact of this decision on the long-term cash-flow of a small or medium sized company, lack of a well-structured strategic approach when making fixed-asset decisions is a major problem area for SMEs operating in Turkey (Guler, 2010; Çetin \& Bitırak, 2009). As generally the funds tied to the acquisitions of fixed-assets, such as buildings or equipment, are in large amounts with long maturity periods, problems in fixed asset investment decisions potentially carry the risk of threatening the cash requirements of daily production/service operations, particularly when the cashflow impact is not clearly analyzed before making the investment. A careful and detailed technical evaluation is a major requirement for making a successful fixed-asset acquisition, as in most cases, the contribution of the investment to the overall productivity and performance of the company becomes highly questionable without a feasibility analysis conducted beforehand. As the basic motivation behind fixed-asset investments in small businesses is "to increase the efficiency, thus profitability of the enterprise" (Zimmerer and Scarborough, 2005), the errors and deficiencies in making these decisions and acting accordingly harm the profitability thereby the financial and overall performance of the company, while inadequate investments towards having more advanced production or service facilities limits the growth of the organization, which underline the importance of a strategic outlook when taking and implementing fixed asset investment decisions. The outcomes are likely to be more positive when these vital decisions are made considering the organizational goals such as growth or profitability and directing the limited resources accordingly, starting with the basic questions of "how much that investment is needed for a better overall performance?" and "how can we allocate our limited resources to this investment in the best way possible, if that investment is a requirement for our short and long-term goals and objectives?". This way, the means and ends would be managed in a more proper way, in terms of maximizing the effectiveness and efficiency of the fixedasset acquisition.

Proposition 3 : Strategic fixed-asset management has a positive impact on SME performance.

Strategic financial reporting and analysis: In Turkey, the inadequacy of financial literacy of SME owners and the impact of that problem area on poor managerial and overall performance of SMEs is well documented in various studies (Uluyol, 2013: Kaya \& Alpkan, 2012, Cetin, 2006). Financial reports and statements, particularly main statements such as balance sheet, profit and loss statement and cash flow statement, are "powerful tools" small business owners can use in managing their companies (Hogetts and Kuratko, 1998). However, mostly due to the inadequacy of accounting and finance knowledge of SME owner/managers, studies show that, only $11 \%$ of small business owners/managers "analyze their financial statements as part of the managerial planning and decisionmaking processes" (Zimmerer and Scarborough, 2005). Evaluation of financial reports presenting the trends and snapshots of past and current financial performance of the company act as the "control and feedback" function of strategic financial management process., thus, lack of information on the financial situation and crucial performance indicators threatens the overall awareness of the company owner required for a sound strategy formulation and implementation., whereas the performance of the enterprise is positively impacted when this important follow-up function is executed on a timely, rational and knowledge-based basis. Therefore, it can be proposed that, the utilization of a "deliberate" strategic management approach, resulting from the formal and rational nature of the feedback and control phase of the strategic management, would significantly improve of SME performance, by pointing out the red and green signals about the past and current major financial performance indicators such as sales growth, profitability or debt/total assets ratio and about the optimum and actual levels of critical balance sheet items such as cash, receivables, inventory, payables and fixed-assets, when managing the financial operations of the company.

Proposition 4: Strategic financial reporting and control has a positive impact on SME performance.

\section{4 . Discussion and conclusion}

The significance of SMEs in the social and economic context, have been recognized worldwide, particularly after 1980 's, and since then, factors affecting the development and growth of SMEs have been among the key concerns of public authorities, academicians and business circles. Although a number of empirical studies investigated various financial management practices and their impact on organizational performance in different countries, the main focus of previous SME finance literature, particularly in developing countries, have been the challenges SMEs face to access to financial resources. However, the efficient utilization of the obtained funds, such as having a sound cash management system, is equally important, for the survival of SMEs. Thus, the shift of research on financial management in SMEs from the one-dimensional "funding focus", towards a more comprehensive "strategic financial management" perspective has the potential to provide positive implications for academics and policy makers, as 
well as practitioners of SME financial management in terms of introducing new dimensions and factors to the concept of improving SME performance.

The conceptual model, which is designed to present how the strategic management practices are interrelated with each other and with the overall organizational performance and which type of strategic management approach is more appropriate for a specific financial management practice, underlines the importance of a strategic perspective for an efficient and effective conduct of the financial management, in order to achieve a successful business performance. The analysis of specific elements of strategic financial management practices of the model, namely strategic financial planning, strategic working capital management, strategic fixed-asset management and strategic financial reporting and control practices, and to what extent the execution of an "emergent" or "deliberate" strategic management approach in the conduct of these financial management practices would lead to better performance results, can provide significant contributions to SME financial management.

This new approach also has the potential to lead a way to future empirical studies conducted to test the impact of the strategic financial management practices on indicators of SME performance, such as growth or profitability. This way, it can contribute to the previous studies investigating the factors of success and failure in SMEs, from a financial management perspective, combined with a strategic management outlook. The key practices regarding financial management conduct can differ from one context to another, therefore other interesting research areas would be the investigations on the variance of the strategic management practices in SMEs operating in different contexts, or with that of larger companies.

\section{REFERENCES}

Alkış, H., \& Temizkan, V. (2012). Kobi'lerin

Yönetsel Sorunlarının Cözümünde

Japon Yönetim Sisteminin Rolü.

Karabük Üniversitesi Sosyal Bilimler

Enstitüsü Dergisi, 2(1).

Ardic, O.; Mylenko, N. and Saltane, V. (2011).

Small and Medium Enterprises A

Cross-Country Analysis with a New

Data Set. World Bank Policy Research

Paper 5538.
Arslan, Ö. (2003). Küçük ve Orta Ölçekli

İşletmelerde Çalışma Sermayesi ve

Bazı Finansal Yönetim Uygulamaları.

Cumhuriyet Üniversitesi, İ.İ.B.F.

Dergisi, 4 (1): 121-135.

Arı, A. (2013). KOBİ'ler, Esnaf ve Sanatkarlar

Özel İhtisas Komisyonu Raporu.

Trakya Kalkınma Ajansı. http :// www

.trakya 2023 .com /uploads /docs /0907

2013y l8AAu.pdf

Ayrıçay, Y. (2010). Ekonomik Krizin Sanayi

Kuruluşları Üzerine Etkisi: İşletme

Finansına İlişkin Bir Çalışma/Effects of

Economic Crisis on Industrial

Enterprises: A Study about Business

Finance. Atatürk Üniversitesi Sosyal

Bilimler Enstitüsü Dergisi, 14(1).

Beck, T. (2010). SME Finance: What Have We Learned and What Do We Need to Learn? The Financial Development Report: 187-195.

Bolton, J. E. (1971). Small firms: Report of the Commission of Inquiry on Small Firms. London, Her Majesty's Stationary Office.

Butt, B.; Hunjra, A.; and Rehman, K. (2010).

Financial Management Practices and Their Impact on Organizational 
Performance. World Applied Sciences Journal, 9(9): 997-1002.

Carter, N. M. (1990). Small Firm Adaptation: Responses of Physicians' Organizations to Regulatory and Competitive Uncertainty. Academy Of Management Journal, 33(2): 307-333.

Chen, M.J. and Hambrick D. C. (1995). Speed, Stealth, and Selective Attack: How Small Frrms Differ From Large Firms in Competitive Behavior. Academy Of Management Journal, 38(2): 453-482.

Chung, S. and Chuang, J. (2011). The Effect of Financial Management Practices on Profitability of Small and Medium Enterprise in Vietnam. Miho University, http://ir.meiho.edu.tw/handle/98765432 $1 / 1473$.

Cohn, T. and Lindberg R.A. (1974). Survival and Growth: Management and Strategies for the Small Firm. New York: American Management Association.

Çakır, H.M.(2013). Nakit Döngüsünün Firma Karlılığına Etkisinin Sektörel Analizi. Journal of Yaşar University, 30 (8): 4948-4965.
Çetin, A. C.; Akyüz, Y; and Genç E. (2011). Küresel Kriz Sürecinde İmalat Sanayi İşletmelerinin Finansal Sorunlarının Değerlendirilmesi Uşak İli Örneği. Journal of Suleyman Demirel University Institute of Social Sciences, 1(13): 55-68.

Çetin, A. C. and Bitırak, İ. A. (2009). Antalya İli Küçük ve Orta Ölçekli İşletmelerinde Finansal Yönetim, İşletme Sermayesi ve Yatırım Bütçelemesi Uygulamaları. Akdeniz Üniversitesi Alanya İşletme Fakültesi Dergisi, 1(1): 119-137.

Davig, W. (1986). Business Strategies in Smaller Manifacturing Firms. Journal Of Small Business Management, 24(1): 38-46.

Dean, T. J.; Brown, R. L.; and Bamford, C. E. (1998). Differences in Large and Small Firm Responses to Environmental Context: Strategic Implications From a Comparative Analysis of Business Formations. Strategic Management Journal, 19(8): 709-726.

European Commission. (2012). Annual Report on Small and Medium-sized 
Enterprises in the EU: EU SMEs in 2012: At the crossroads.

Güler, S. (2010). İstanbul Menkul Kiymetler Borsasına (İMBK) Kayıtlı Küçük ve Orta Büyüklükteki İşletmelerin (KOBİ) Sermaye Yapıları Üzerine Bir Uygulama. Suleyman Demirel University, The Journal of Faculty of Economics and Administrative Sciences, 15(3): 353-371.

Güngör, N. and Öndeş, T. (2013). Kobi'lerin Finansmanı Erzurum Organize Sanayi Bölgesinde Bir Araştırma. İktisadi ve İdari Bilimler Dergisi/Journal of Economics and Adminstrative Sciences, 27(1): 59-71.

Hall, G. and Young, B. (1991). Factors Associated with Insolvency Amongst Small Firms. International Small Business Journal, 9(2): 54-63.

Hallberg, K. (2000). A Market-Oriented Strategy for Small and Medium-Scale Enterprises. IFC Discussion Paper 40.

Hunjra, A. I.; Butt, B. Z.; and Rehman, K. U. (2010). Financial Management Practices and Their Impact on Organizational Performance. World
Applied Sciences Journal, 9(9): 9971002.

Jindrichovska, I. (2013) Financial Management in SMEs. European Research Studies Journal, 16 (Special Issue on SMEs): 79-96.

Jindrichovska, I.; Ugurlu, E.; and Kubickova, D.. (2013). Changes in Capital Structure of Czech SMEs: A Dynamic Panel Data Approach, Ekonomika a Management, 2(3): 36-49.

Kaya, S. and Alpkan, L. (2012). Problems and Solution Proposals for SMEs in Turkey, EMAJ: Emerging Markets Journal, 2(2): 178-196.

Kennedy, J. and Tennent, B. (2006). Financial Management Practices in Small Businesses: Regional and Metropolitan. Small Enterprise Research, 14(1): 5563.

KOSGEB. (2011) KOBİ Stratejisi ve Eylem Planı 2011-2013, http: //www . sanayi. gov $\quad$ tr $\quad /$ Files/Documents/KOSGEB_Katalog.pd f

KOSGEB.(2012). Enhancing The Competitiveness Of SMEs in Turkey, Country 
Report.http://www.comcec.org/UserFil

es/File/\%C3\%BClkeraporlar\%C4\%B1/

28_isedak_\%C3\%BClke_rap/T\%C3\%

BCrkiye.pdf.

Koyuncugil, A. S.; and Ozgulbas, N. (2006). Is

There a Specific Measure for Financial

Performance of SMEs. The Business

Review, Cambridge, 5(2): 314-319.

Kutlu, H. A. and Demirci, N. S. (2007), Kobi'lerin Finansal Sorunları ve Çözüm Önerileri. 4. KOBİ'ler ve Verimlilik Kongresi.

Liberman-Yaconi, L.; Hooper, T.; and Hutchings, K.. (2010). Toward a Model of Understanding Strategic DecisionMaking in Micro-Firms: Exploring the Australian Information Technology Sector. Journal Of Small Business Management, 48(1): 70-95.

Liu, Z. (2010). Strategic Financial Management in Small and MediumSized Enterprises, International Journal of Business \& Management, 5(2): 887894.

Lukács, E. (2005). The Economic Role of SMEs in the World Economy, Especially in Europe, European Integration Studies, 1(4): 3-12.
McMahon, R. Holmes, P.; Hutchison, S.; and Forsaith, M. (1993). Small Business Financial Management: Theory and Practice, Journal of Management, l (15): 5-19.

Meredith, G. G. (1986). Financial Management of the Small Enterprise. McGraw-Hill, Sydney, New South Wales.

Mintzberg, H. (1994). Rise and fall of strategic planning. Simon and Schuster.

Nguyen, K. M. (2001). Financial Management and Profitability of Small and Medium Enterprises. Theses..

Nurrachmi, R. N.; Abd Samad, K.; and Foughali, I. (2012). The Development of SMEs in Turkey. Strategic Management Journal, 11: 124-136.

OECD, Organisation for Economic Cooperation and Development (2004). Small and Medium-Sized Enterprises in Turkey, Issues and Policies. http:// www. oecd. org/ industry /smes /3193 2173.pdf

OECD, Organisation for Economic Cooperation and Development (2006). The SME Financing Gap (Vol. I): Theory and Evidence. OECD. 
OECD, Organisation for Economic Cooperation and Development (2012). SME Policy Index Western Balkans and Turkey,2012. OECD.

Okafor, R. G. (2012). Financial Management Practices of Small Firms in Nigeria: Emerging Tasks for the Accountant, European Journal of Business and Management, 4(19): 159-169.

Ondes, T. \& Gungor, N. (2013). Kobi'lerin Finansmani Erzurum Organize Sanayi Bolgesinde Bir Arastirma. Ataturk University Journal of Economics and Admistrative Sciences, 27 (1).

Özdemir, S.; Ersöz, H. Y.; and Sarıoğlu, H. İ. (2011). Küçük Girişimciliğin Artan Önemi ve KOBİ'lerin Türkiye Ekonomisindeki Yeri. Sosyal Siyaset Konferanslar1 Dergisi, 12(3): 67-83.

Peel, M. J. and Wilson, N. (1996) Working Capital and Financial Management Practices in the Small Firm Sector, International Small Business Journal, 14(2): 52-68.

Pham, H. (2010). The Impact of Financial Management Practices on Profitability of Small and Medium Enterprises (SMEs) in Vietnam. Master's Thesis.
Pleitner, Hans J. (1989). Strategic Behavior in Small and Medium-Sized Firms: Preliminary Considerations.". Journal of Small Business Management, 27 (4): 70-75.

Salazar, A. L.; Soto, R. C.; and Mosqueda, R. E. (2012). The Impact of Financial Decisions and Strategy on Small Business Competitiveness, Global Journal of Business Research (GJBR), 6(2): 332-349.

Snodgrass, D. R. and Biggs, T. (1996). Industrialization and the Small Firm: Patterns and Policies. ICS Press.

Storey, D. J. (1994) Understanding the Small Business Sector. Cengage Learning EMEA.

Şahin, O. (2011). Kobi'lerde Finansal Performans1 Belirleyen Faktörler. Zonguldak Karaelmas University Journal of Social Sciences, 7(14): 7691.

Topal, Y.; Erkan, M.; Elitaş, C. (2006). Küçük ve Orta Boy İşletmelerin Finansal Yönetim Uygulamaları: Afyonkarahisar Örneği, Süleyman Demirel Üniversitesi, İ.İ.B.F. Dergisi, 11(1): 281-298. 
Tolentino, A. L. (1995. Guidelines for the Analysis of Policies and Programmes for Small and Medium Enterprise Development, International Labour Office.

TURKSTAT, Turkish Statistical Institute. (2013). http://www. turkstat . gov . tr / Pre HaberBultenleri.do?id=15881..

Wheelen, L. T. and Hunger, D. (2010). Strategic Management and Business Policy-Achieving Sustainability. Pearson International Edition.

Wickham, P. A. (2006). Strategic Entrepreneurship. Pearson Education.

Wilson, I. (1994). Strategic Planning Isn't Dead-It Changed. Long range planning, 27 (4): 12-24.

Worldbank. (2014). Doing Business Report. http://www.doing business .org /data /explore economies/turkey/

Zimmerer, T. W. and Scarborough, N. M. (2005). Essentials of Entrepreneurship and Small Business Management: the Foundations of Entrepreneurship, The United States of America: Pearson Education.
Zonooz, B. H.; Farzam, V.; Satarifar, M.; and Bakhshi, L. (2011). The Relationship Between Knowledge Transfer and Competitiveness in "SMEs" with Emphasis on Absorptive Capacity and Combinative Capabilities, International Business and Management, 2(1): 56-78. 